\title{
Annexin A2 and A5 Serve as New Ligands for C1q on Apoptotic Cells*
}

Received for publication, January 10, 2012, and in revised form, August 1, 2012 Published, JBC Papers in Press, August 9, 2012, DOI 10.1074/jbc.M112.341339

Myriam Martin ${ }^{1}$, Jonatan Leffler, and Anna M. Blom ${ }^{2}$

From the Department of Laboratory Medicine Malmö, Lund University, Medical Protein Chemistry, Inga Marie Nilssons gata 53, S-205 02 Malmö, Sweden

Background: C1q opsonizes apoptotic cells to facilitate clearance.

Results: Annexin A2 and A5 as well as DNA and histones serve as ligands for C1q on apoptotic cells.

Conclusion: Disturbances in the interaction between $\mathrm{C} 1 \mathrm{q}$ and these ligands might exacerbate autoimmune diseases.

Significance: The knowledge of new $\mathrm{C} 1 \mathrm{q}$ ligands helps to further the understanding of autoimmune diseases.

$\mathrm{C} 1 \mathrm{q}$ is the initiator of the classical complement pathway and opsonizes apoptotic cells to facilitate phagocytosis. Deficiency of $\mathrm{C1q}$ is the strongest known risk factor for development of systemic lupus erythematosus (SLE), which appears to be related to ensuing impaired clearance of apoptotic material. The objective of the current study was to investigate new ligands for $\mathrm{C1q}$ on the surface of apoptotic cells. We revealed that the two phospholipid-binding proteins annexin A2 and A5 are, beside DNA, significant $\mathrm{C} 1 \mathrm{q}$ ligands. We furthermore, demonstrated that C1q binds directly to histones exposed on the surface of dying cells but we did not detect significant interaction with phosphatidylserine. The complement inhibitors C4b-binding protein and factor $\mathrm{H}$ also interact with dying cells, most likely to decrease complement activation beyond the level of $\mathrm{C} 3$ to allow noninflammatory clearance. Despite the fact that $\mathrm{C} 4 \mathrm{~b}$-binding protein, factor $\mathrm{H}$, and $\mathrm{C1q}$ share some ligands on dying cells, we showed that these three proteins did not compete with one another for binding to apoptotic cells. We additionally demonstrated that the way in which apoptosis is induced influenced both the degree of apoptosis and the binding of C1q. The knowledge, that annexin A 2 and $\mathrm{A} 5$ act as ligands for $\mathrm{C} 1 \mathrm{q}$ on apoptotic cells, sheds new light on the pathophysiology of autoimmune diseases.

The complement system constitutes an integral part of innate immunity and serves as a first line of defense against many pathogens. Besides this, it contributes significantly to clearance of immune complexes and dying cells (1). The classical complement pathway is initiated when the C1-complex binds its target, e.g. apoptotic cells, which triggers a cascade of proteolytic cleavages of downstream complement proteins (2). The globular head domains of the C1q subunit comprise the recognition units of the $\mathrm{C} 1$ complex. There are six head

* This work was supported in part by the Söderberg Foundation, Swedish Research Council Grant K2009-68X-14928-06-3, the Swedish Foundation for Strategic Research, the Swedish Rheumatism Association, the National Board of Health and Welfare and Skåne University Hospital, and the Österlund, Greta and Johan Kock, King Gustaf V's 80th Birthday, Knut and Alice Wallenberg, and Inga-Britt and Arne Lundberg Foundations.

${ }^{1}$ Supported by a postdoctoral stipend from the Crafoord Foundation.

${ }^{2}$ To whom correspondence should be addressed. Tel.: 46-40-338233; Fax: 46-40-337043; E-mail: Anna.Blom@med.lu.se. domains to each $\mathrm{C} 1 \mathrm{q}$ molecule and simultaneous binding of several ligands is required for activation of $\mathrm{C} 1$. Some $\mathrm{C} 1 \mathrm{q}$ ligands are known to bind the N-terminal collagen-like stalk region but these usually do not trigger the classical pathway. C1q binds to surface blebs of apoptotic cells (3) and the interaction is mediated by the globular head region of $\mathrm{C} 1 \mathrm{q}$ causing complement activation and deposition of $\mathrm{C} 3 \mathrm{~b}$ on dying cells $(4-7)$. The aim of the current study was to investigate new ligands for $\mathrm{C} 1 \mathrm{q}$ on the surface of apoptotic cells. So far the only widely accepted $\mathrm{C} 1 \mathrm{q}$ ligand on dying cells is DNA, which becomes accessible already very early on apoptotic cells, even before phosphatidylserine $(\mathrm{PS})^{3}(8)$. However, the precise region of $\mathrm{C} 1 \mathrm{q}$ involved in DNA binding is a matter of controversy, because both the collagen-like stalk region and the globular head region have been implicated $(7,9-12)$. C1q has also been proposed to bind PS (13). C1q appears to bind relatively late apoptotic cells and necrotic cells.

Two complement inhibitors, C4b-binding protein (C4BP) and factor $\mathrm{H}(\mathrm{FH})$, have also been shown to interact with apoptotic and necrotic cells (14-16). The binding of C4BP, which circulates mainly in complex with protein $\mathrm{S}$, to dying cells is mediated by interaction of protein S with PS (14) and to a much lesser extent via an interaction of the C4BP $\alpha$-chains with DNA (16). In comparison, we showed recently that FH binds to annexin A2, DNA, and histones on the surface of apoptotic cells (17). These two complement inhibitors interfere with the cascade at the $\mathrm{C} 3$ level to minimize proinflammatory and lytic effects of full-blown complement activation. They also compensate for the loss of membrane-bound complement inhibitors such as membrane cofactor protein (MCP, CD46), which in turn, when down-regulated during apoptosis, act as an "eatme" signal for effective clearance (8). Efficient and noninflammatory clearance of dying cells is crucial to avoid autoimmune reactions. Failure to do so, for example, in the case of genetic $\mathrm{C} 1 \mathrm{q}$ deficiency, is proposed to be one of the underlying mechanisms in systemic lupus erythematosus (SLE). In SLE, autoantibodies directed against antigens present on dying cells are

\footnotetext{
${ }^{3}$ The abbreviations used are: PS, phosphatidylserine; $A 2$, annexin A2; A5, annexin $\mathrm{A} 5$; $\alpha 1$-AT, $\alpha$-antitrypsin; C4BP, C4b-binding protein; $\mathrm{FH}$, factor $\mathrm{H}$; $\mathrm{Hi}-\mathrm{NHS}$, heat inactivated normal human serum; NHS, normal human serum; PC, phosphatidylcholine; PE, phosphatidylethanolamine; SLE, systemic lupus erythematosus.
} 
frequently found, which indicates less efficient or proinflammatory clearance of effete cells. Reasons for induced inflammatory clearance range from genetic or acquired deficiencies of $\mathrm{C} 1 \mathrm{q}$ to potential alterations in ligands for proteins that prevent inflammatory clearance, such as the fluid phase complement inhibitors. Autoantibodies directed against apoptotic cells might further promote an Fc $\gamma \mathrm{R}$-mediated clearance, which is proinflammatory. Autoantibodies might also block binding sites for opsonins or complement inhibitors. Autoantibodies directed against annexins have been described in SLE (18).

Annexins are unique proteins that interact with membrane phospholipids in a $\mathrm{Ca}^{2+}$-dependent manner, providing a link between $\mathrm{Ca}^{2+}$ signaling and membrane functions. The human annexin protein family encompasses over 10 members, which are involved in intracellular transport and function as bridging molecules to phospholipid membranes (19). It has been suggested that they play a role in many types of diseases including autoimmune diseases such as SLE (20-22). Annexin A5 is also widely used as an apoptotic marker because it recognizes PS on the surface of apoptotic cells.

In the current study, we further characterized the proposed binding partners for $\mathrm{C} 1 \mathrm{q}$ and $\mathrm{C} 4 \mathrm{BP}$ on apoptotic cells, and identified annexin A2 and A5 as new ligands for C1q. This knowledge helps to further the understanding of the pathophysiology of autoimmune diseases such as SLE.

\section{EXPERIMENTAL PROCEDURES}

Cells and Induction of Cell Death-Jurkat T-cells (ATCC) were grown in RPMI containing glutamine and 10\% heat-inactivated fetal calf serum (all from Invitrogen). Apoptosis was generally induced using $0.75 \mu \mathrm{M}$ staurosporine (Sigma) for $16 \mathrm{~h}$ in RPMI without fetal calf serum at $37^{\circ} \mathrm{C}$ and $5 \% \mathrm{CO}_{2}$. Apoptosis was additionally induced for $4 \mathrm{~h}$ using: $1 \mu \mathrm{M}$ staurosporine, $10 \mu \mathrm{M}$ camptothecin, $100 \mu \mathrm{M}$ etoposide, $10 \mu \mathrm{M}$ actinomycin D, or $100 \mu \mathrm{M}$ cyclohexamide, all from Calbiochem or anti-fas and protein G (each $1 \mu \mathrm{g} / \mathrm{ml}$ ), from Calbiochem and Sigma, respectively.

Isolation of Primary T-lymphocytes-Peripheral blood leukocytes were isolated from leukocyte filters within $5 \mathrm{~h}$ of blood donation. Cells were washed from the filter using PBS with 2 mM EDTA (PBS/EDTA), and peripheral blood mononuclear cells were isolated by density media centrifugation using Lymphoprep (Axis Shield) according to the supplied instructions. Isolated peripheral blood mononuclear cells were washed twice in PBS/EDTA and total $\mathrm{CD} 4^{+} \mathrm{T}$ cells were purified by positive selection using anti-CD4 coupled magnetic beads (Miltenyi Biotech) according to supplied instructions, with an average purity of over $95 \%$. Isolated $\mathrm{CD} 44^{+} \mathrm{T}$-cells were resuspended in RPMI for further use.

Proteins, Antibodies, and Sera-The C4BP-protein S complex (23), FH (24), C1q (25), protein S (26), and $\alpha 1$-anti trypsin (27) were purified from human plasma as described. The preparation of stalk and head portions of $\mathrm{Clq}$ was performed according to published protocols (28), where pepsin (Worthington) and collagenase (from Clostridium histolyticum, Worthington), respectively, were used for partial digestion of $\mathrm{C} 1 \mathrm{q}$. Histones $(\mathrm{H} 2 \mathrm{~A} / \mathrm{H} 2 \mathrm{~B}+\mathrm{H} 1$ and $\mathrm{H} 3 / \mathrm{H} 4)$ were purified from Jurkat T-cells (17), human IgG were from Immuno, annexin A2
(437622) was from Calbiochem, and annexin A5 (5165871A) from BD Biosciences. All isolated proteins were at least 95\% pure, as judged by Coomassie staining of proteins separated by SDS-PAGE. Antibodies used were: anti-dsDNA (21227771, Immunotools), anti-C4BP PK9008 (home made), anti-FH (A312, Quidel), anti-C1q (A0136, Dako), anti-C4c (Q0369, Dako), anti-annexin A2 (ab41803, Abcam), and anti-annexin A5 (ab14196, Abcam). Secondary antibodies horseradish peroxidase-conjugated were anti-rabbit (P0399, Dako) and antigoat (P0449, Dako), and fluorescently labeled were anti-rabbit Alexa Fluor 647 (A21246, Invitrogen), anti-mouse Alexa Fluor 488 (A11059, Invitrogen), and anti-goat Alexa Fluor 647 (A21446, Invitrogen). Normal human serum (NHS) and heatinactivated serum (Hi-NHS) were prepared as described (26) according to a permit granted by the Ethics Committee of Lund University. C1q-deficient sera (A112) and normal control sera (A509) were purchased from Quidel.

Labeling of Proteins with Fluorescent Dyes-C1q, C4BP, and FH were either labeled with Alexa Fluor 488 (Invitrogen) or DyLight 488 (Pierce), respectively, following the manufacturer's instructions. C1q was easily negatively affected by the labeling and therefore sometimes was replaced with unlabeled protein followed by detection with antibodies.

Complement Deposition and Binding Assay-For deposition assays, $2.5 \mu \mathrm{g} / \mathrm{ml}$, and for binding assays, $4 \mu \mathrm{g} / \mathrm{ml}$ of annexin $\mathrm{A} 2$, annexin $\mathrm{A} 5, \mathrm{H} 2 \mathrm{~A} / \mathrm{H} 2 \mathrm{~B}+\mathrm{H} 1$, and $\mathrm{H} 3 / \mathrm{H} 4$ were coated onto a Maxisorp (Nunc) microtiter plate in $75 \mathrm{~mm}$ sodium carbonate buffer, $\mathrm{pH} 9.6$, at $4{ }^{\circ} \mathrm{C}$ overnight. Aggregated IgG $(2.5 \mu \mathrm{g} / \mathrm{ml}$ for deposition and $2 \mu \mathrm{g} / \mathrm{ml}$ for binding assays) was used as positive control, $1 \%$ BSA or $4 \mu \mathrm{g} / \mathrm{ml}$ of $\alpha 1$-antitrypsin were used as negative controls. The unbound proteins were washed with 50 $\mathrm{mm}$ Tris- $\mathrm{HCl}, 150 \mathrm{~mm} \mathrm{NaCl}$, and $0.1 \%$ Tween 20, pH 7.5 (immunowash), blocked in 1\% BSA (binding assays) or immunowash containing 3\% fish gelatin (deposition assays), washed, and incubated with either NHS or Hi-NHS in $5 \mathrm{~mm}$ veronal buffer with $0.1 \%$ gelatin, $1 \mathrm{~mm} \mathrm{MgCl}_{2}$, and $0.15 \mathrm{~mm} \mathrm{CaCl}_{2}$ $(\mathrm{GVB}++)$ or purified proteins in $50 \mathrm{~mm}$ HEPES, $\mathrm{pH}$ 7.4, 150 $\mathrm{mM} \mathrm{NaCl}, 2 \mathrm{mM} \mathrm{CaCl} 2,50 \mu \mathrm{g} / \mathrm{ml}$ of BSA for $2 \mathrm{~h}$ at room temperature (binding assays) or $25 \mathrm{~min}$ at $37^{\circ} \mathrm{C}$ (deposition assays). For competition studies, the purified proteins were preincubated with 5 to $25 \mathrm{M}$ excess of additional proteins for $45 \mathrm{~min}$ at room temperature, in 50 mм HEPES, pH 7.4, $150 \mathrm{~mm} \mathrm{NaCl}, 2$ $\mathrm{mm} \mathrm{CaCl}_{2}, 50 \mu \mathrm{g} / \mathrm{ml}$ of BSA, washed, incubated with antibodies specific for $\mathrm{C} 1 \mathrm{q}, \mathrm{C4c}$, or $\mathrm{FH}$, washed and incubated with appropriate horseradish peroxidase-conjugated secondary antibody, and developed using OPD tablets (Dako) according to the manufacturer's instructions. Absorbance was measured at $490 \mathrm{~nm}$ in a Cary50 Bio UV spectrophotometer connected to a 50MPR microplate reader (Varian). For assessment of ionic strength dependence, the same basic assay was used. However, $10 \mu \mathrm{g} / \mathrm{ml}$ of $\mathrm{C} 1 \mathrm{q}$ was incubated in binding buffer with $\mathrm{NaCl}$ concentrations ranging from 0 to $1000 \mathrm{~mm}$. The binding assay assessing calcium/magnesium dependence was performed using binding buffer supplemented with 5 or 20 mM EDTA.

Binding of Radiolabeled Proteins to C1q Heads and Tails-4 $\mu \mathrm{g} / \mathrm{ml}$ of purified C1q, C1q globular heads, and collagenous tails were coated as above. $1 \%$ BSA or $4 \mu \mathrm{g} / \mathrm{ml}$ of $\alpha_{1}$-antitrypsin were used as negative controls. The unbound proteins were 
A
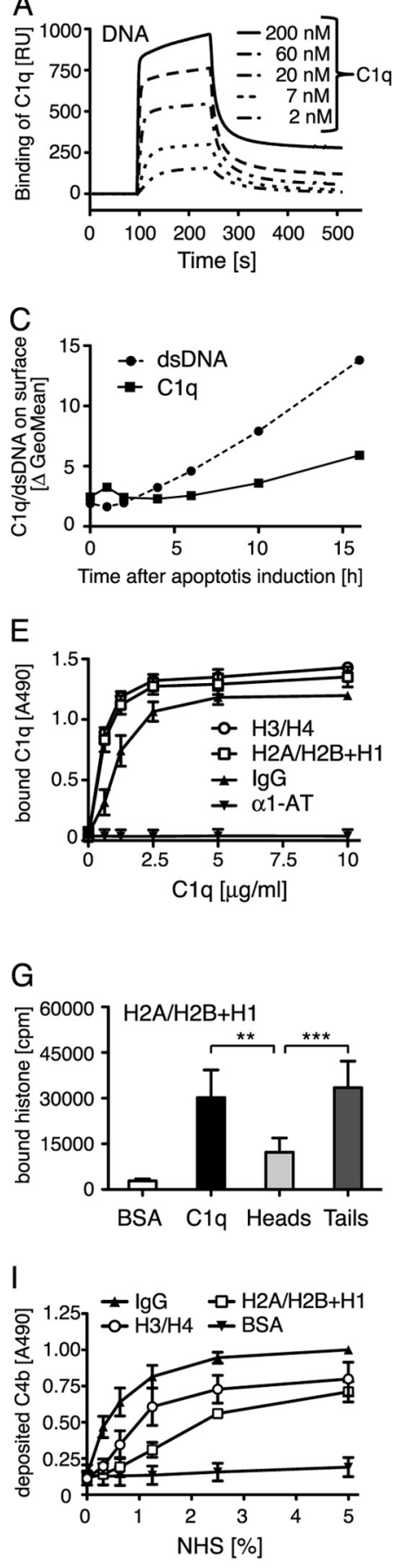

B

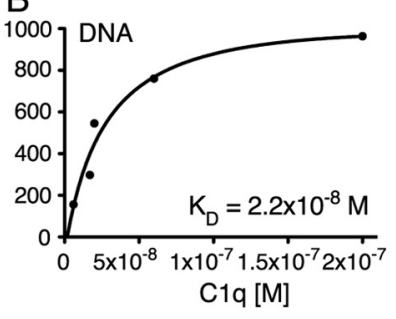

D
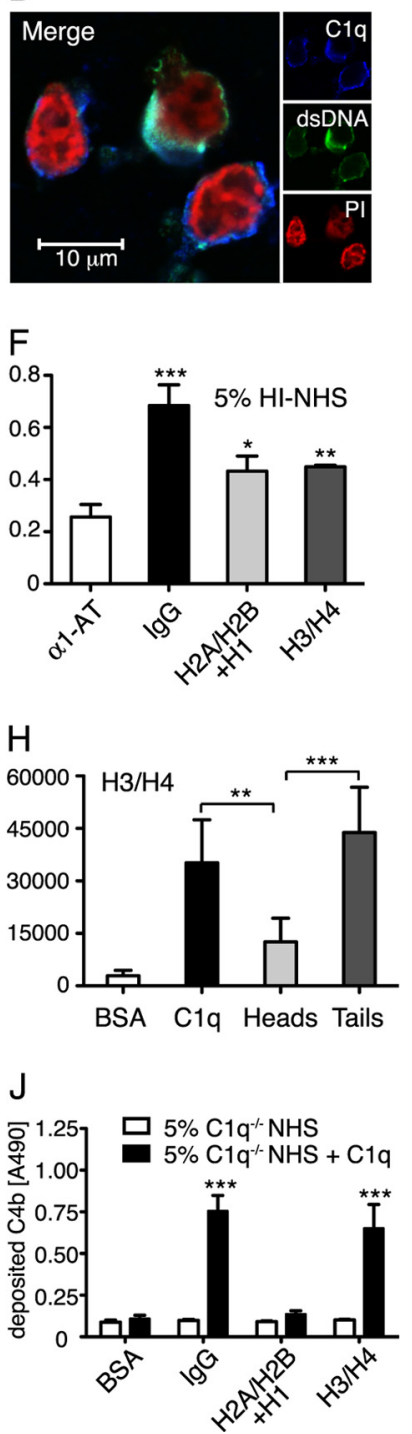

FIGURE 1. C1q binds DNA and histones. $A$, increasing concentrations of $\mathrm{C} 1 \mathrm{q}$ were flown over immobilized biotinylated DNA on a plasmon surface resonance (Biacore) streptavidin chip. Dose-dependent binding of C1q to DNA was observed and is presented in arbitrary response units $(R U)$. B, the response obtained at equilibrium was plotted against $C 1 \mathrm{q}$ concentration and $K_{D}$ value of the C1q DNA interaction was determined to $2.2 \times 10^{-8} \mathrm{M}$. C, by flow cytometry, double-stranded DNA expression and C1q binding (50 $\mu \mathrm{g} / \mathrm{ml}$ ) on apoptotic cells were investigated after the indicated time of apoptosis induction. An increase of expression of dsDNA as well as binding of C1q was seen during the course of apoptosis although the increase was more pronounced for dsDNA than the $\mathrm{C} 1 \mathrm{q}$ binding. $D$, localization of $\mathrm{C} 1 \mathrm{q}$ (blue), dsDNA (green), and propidium iodide (PI) (red) on apoptotic cells was analyzed using confocal microscopy. E, binding of $\mathrm{C} 1 \mathrm{q}$ to immobilized histones, lgG (positive control), and $\alpha 1$-AT (negative control) was analyzed in an ELISA setup. Clear concentration dependent binding was seen for $\mathrm{C} 1 \mathrm{q}$ to both histone complexes. $F$, binding of $\mathrm{Clq}$ from Hi-NHS to immobilized histones or IgG was detected and compared with $\alpha 1-A T$ as a control. $G$ and $H$, radiola-

washed with immunowash, blocked in $1 \% \mathrm{BSA}$, and incubated with ${ }^{125}$ I-radiolabeled histones $\mathrm{H} 2 \mathrm{~A} / \mathrm{H} 2 \mathrm{~B}+\mathrm{H} 1$ and $\mathrm{H} 3 / \mathrm{H} 3$ as well as annexin A2 and A5 in 50 mM HEPES, pH 7.4, $150 \mathrm{~mm}$ $\mathrm{NaCl}, 2 \mathrm{mM} \mathrm{CaCl}_{2}, 50 \mu \mathrm{g} / \mathrm{ml}$ of BSA overnight (for histones) or $5 \mathrm{~h}$ (for annexins) at room temperature. After washing, the radiolabeled bound proteins were measured using a 1277 GammaMaster (LKB Wallac).

Flow Cytometry-For binding or expression analysis by flow cytometry, apoptosis was induced for the indicated time points as above. For liposomes, liposome-coated Dynabeads were prepared as described below. For binding experiments, cells or liposomes were washed in $10 \mathrm{~mm}$ HEPES, $150 \mathrm{~mm} \mathrm{NaCl}, 5 \mathrm{~mm}$ $\mathrm{KCl}, 1 \mathrm{mM} \mathrm{MgCl}_{2}$, and $2 \mathrm{mM} \mathrm{CaCl}_{2}$ (binding buffer) and incubated with unlabeled or labeled proteins. For competition experiments, proteins were preincubated for $30 \mathrm{~min}$ at room temperature with competing protein in 5 to $25 \mathrm{M}$ excess. Proteins in binding buffer were subsequently incubated with cells or liposomes for $30 \mathrm{~min}$ at $37^{\circ} \mathrm{C}$. For experiments with unlabeled proteins or expression analysis, samples were washed in PBS supplemented with $1 \% \mathrm{BSA}$ and $30 \mathrm{mM} \mathrm{NaN}_{3}$, incubated with primary antibody for $30 \mathrm{~min}$, washed, incubated with fluorochrome-labeled secondary antibody for $30 \mathrm{~min}$, washed, and taken up in binding buffer supplemented with $30 \mathrm{~mm} \mathrm{NaN}_{3}$ and analyzed in a CyFlow Space (Partec). For discrimination between live, apoptotic, or necrotic cells, samples were stained with Annexin A5-PE (BD Bioscience) and Via-Probe (BD Bioscience) in binding buffer after antibody staining, incubated 20 min, and analyzed as above.

Confocal Microscopy-Apoptosis was directly induced on SuperFrostPlus object slides (Menzel). Therefore 80,000 cells diluted in RPMI without fetal calf serum containing $1 \mu \mathrm{M}$ staurosporine were pipetted within a Dako Pen inked circle and incubated for the indicated time at $37^{\circ} \mathrm{C}$ in $5 \% \mathrm{CO}_{2}$. After washing twice with $10 \mathrm{~mm}$ HEPES, $150 \mathrm{~mm} \mathrm{NaCl}, 5 \mathrm{~mm} \mathrm{KCl}, 1$ $\mathrm{mm} \mathrm{MgCl}$, and $2 \mathrm{mM} \mathrm{CaCl}_{2}$ (binding buffer), the proteins were added to the cells in a final volume of $30 \mu \mathrm{l}$ and incubated for 30 min at $37^{\circ} \mathrm{C}$ in a humidified chamber. After washing 3 times for 5 min in PBS, the cells were fixed with $3.7 \%$ paraformaldehyde for $15 \mathrm{~min}$, washed again, and centrifuged for $1 \mathrm{~min}$ at $500 \times g$ in a Cellspin (Tharmac). After blocking with PBS $+1 \%$ BSA + $30 \mathrm{~mm} \mathrm{NaN}$ for $30 \mathrm{~min}$ at $37^{\circ} \mathrm{C}$, the primary antibody was incubated either overnight at $4{ }^{\circ} \mathrm{C}$ or for $1 \mathrm{~h}$ at room temperature. After washing, the cells were incubated with the secondary antibody for $1 \mathrm{~h}$ at room temperature followed by washing and addition of $100 \mathrm{ng} / \mathrm{ml}$ of propidium iodide or $50 \mu \mathrm{l}$ of Alexa

beled histone $\mathrm{H} 2 \mathrm{~A} / \mathrm{H} 2 \mathrm{~B}+\mathrm{H} 1$ and $\mathrm{H} 3 / \mathrm{H} 4$ were incubated with immobilized C1q, C1q globular heads, C1q collagenous tails, and BSA (negative control). After washing, the amount of bound protein was determined in a $\gamma$-counter. Binding occurs mainly to the collagenous tail region. I and J, C4b deposition on immobilized histones or controls was measured from NHS (I), C1q-deficient sera or C1q-deficient sera reconstituted with $70 \mu \mathrm{g} / \mathrm{ml}$ of C1q $(J)$. Deposition of $\mathrm{C} 4 \mathrm{~b}$ was detected on all histone complexes from NHS and it decreased in C1q-deficient sera but could only be restored upon addition of $\mathrm{C} 1 \mathrm{q}$ to the $\mathrm{H} 3 / \mathrm{H} 4$ histone complex. For $C$, representative values from two independent experiments are shown. For $D$, one representative image of two independent experiments is shown. $E-H$, values are shown as mean of duplicates, $n=4(G$ and $H)$ and $n=3(E$ and $F, l$ and $J) \pm$ S.D. Significance of differences was calculated using one-way analysis of variance followed by Tukey's $(G$ and $H$ ) or Dunnett's ( $F$ and $J$ ) multiple comparison post-test and is displayed as: ${ }^{*}, p<0.05 ;{ }^{* *}, p<0.01 ;{ }^{* * *}, p<0.001$. 


\section{Annexins Bind C1q}

Fluor-labeled annexin A5 diluted 1:2-1:6 in 10 mM HEPES, 140 mM NaCl, $2.5 \mathrm{~mm} \mathrm{CaCl}_{2}, \mathrm{pH}$ 7.4, for $15 \mathrm{~min}$. For annexin A5 staining, the cells where preincubated for $30 \mathrm{~min}$ and washed with the corresponding $\mathrm{Ca}^{2+}$-containing buffer. After the final wash, the slides were briefly dipped in 99\% ethanol, dried, and mounted with DakoCytomation fluorescent mounting medium. All slides were analyzed in a LSM 510 Meta confocal microscope (Zeiss); co-localization was calculated using CoLocalizer Express (CoLocalization Research Software).

Liposome Preparation-All used phospholipids are listed in Table 1. They were purchased from Avanti Polar Lipids and kept in chloroform with $10 \%$ methanol at $-20{ }^{\circ} \mathrm{C}$. For surface plasmon resonance experiments, lipids were mixed in the desired molar ratios and the chloroform was removed. Liposomes were generated by extrusion. Lipids were resuspended in $10 \mathrm{~mm}$ HEPES, pH 7.4, and $150 \mathrm{~mm} \mathrm{NaCl}$, frozen, and thawed 5 times using dry ice/acetone and a $40{ }^{\circ} \mathrm{C}$ water bath, extruded 19 times through two polycarbonate membranes with 100-nm pores (Avestin) using a LiposoFast-Basic (Avestin), and stored at $4{ }^{\circ} \mathrm{C}$ for use within 7 days. For flow cytometric assays, $1 \mu \mathrm{mol}$ of lipids in the desired molar ratio were mixed with $10 \mathrm{nmol}$ of $N$-(biotinyl)-1,2-dihexadecanoyl-sn-glycero-3-phosphoethanol-amine, triethylammonium (Invitrogen), and $6.4 \mathrm{nmol}$ of 2-(3-(diphenylhexatrienyl)propanoyl)-1-hexadecanoyl-sn-glycero-3-phosphocholine (Invitrogen), chloroform was evaporated and lipids were resuspended in $25 \mathrm{~mm}$ HEPES and $150 \mathrm{~mm}$ $\mathrm{NaCl}$, pH 7.7 (HBS), sonicated, and mixed with M-280 streptavidin-coated Dynabeads (Invitrogen) as previously described.

Surface Plasmon Resonance-To measure the kinetics of the DNA-C1q interaction, biotinylated DNA was coupled to a streptavidin-coated SA chip (GE Healthcare). Double-stranded 25-mer oligonucleotides $(\mathrm{G}-\mathrm{C})_{25}$ and $(\mathrm{A}-\mathrm{T})_{25}$ were produced using equimolar amounts of single-stranded 5 '-biotinylated 25-mer oligonucleotides (MWG) as described (16). Briefly, equal concentrations of $\mathrm{G}-\mathrm{C}$ and $\mathrm{A}-\mathrm{T}$ were coupled to the streptavidin sensor chip surface to a level of 300 response units (Biacore 2000, GE Healthcare). All experiments were performed at a continuous flow rate of $30 \mu \mathrm{l} / \mathrm{min}$ using running buffer (150 mm NaCl, $10 \mathrm{~mm}$ HEPES, $2.5 \mathrm{~mm} \mathrm{CaCl}_{2}, 0.002 \%$ Tween 20, pH 7.4). C1q was run over the chip in a concentration gradient from 2 to $200 \mathrm{~nm}$. The chip was regenerated using pulse injection of $3 \mathrm{M}$ guanidium chloride followed by $1 \mathrm{M} \mathrm{NaCl}$. The obtained sensograms were analyzed using Bio-evaluation software 3.0 (GE Healthcare).

To measure kinetics of lipid-protein interactions (29) the lipophilic L1 sensor chip was washed for $1 \mathrm{~min}$ at a flow of 20 $\mu \mathrm{l} / \mathrm{min}$ with $40 \mathrm{~mm} n$-octyl- $\beta$-D-glucopyranoside (Calbiochem). Phospholipid liposomes $(500 \mu \mathrm{M})$, generated by extrusion, were injected for $17 \mathrm{~min}$ at a $3 \mu \mathrm{l} / \mathrm{min}$ flow rate in HBS running buffer. The average immobilization level for all liposomes was 1000 response units. The chip was then washed five times with $10 \mathrm{~mm}$ EDTA, pH 8.0, injections ( $2 \mathrm{~min}$ at 20 $\mu l / \min )$, after which the membrane surface was stable. For protein binding experiments, running buffer was changed to $\mathrm{HBC}$ (HBS with $10 \mathrm{mg} / \mathrm{ml}$ of BSA and $5 \mathrm{mM} \mathrm{CaCl}_{2}$ ) and flow cells were equilibrated until the baseline stabilized. Purified $\mathrm{C} 1 \mathrm{q}$ and $\mathrm{C} 4 \mathrm{BP}$ were diluted in $\mathrm{HBC}$ and injected over the liposome surfaces at several serial dilutions ranging from 400 to $6 \mu \mathrm{g} / \mathrm{ml}$. The flow was set at $20 \mu \mathrm{l} / \mathrm{min}$ and the proteins were allowed to associate for $240 \mathrm{~s}$ followed by a 200-s dissociation. The immobilized liposome surface could be regenerated with an injection of $10 \mathrm{~mm}$ EDTA, pH 8.0, which returned the baseline to the value prior to introducing protein. To calculate the dissociation constant $\left(K_{D}\right)$ of interaction between C4BP and liposomes containing 90\% PC, 10\% PS, the response obtained at equilibrium was plotted against each concentration used and the one-site binding hyperbola was fitted using Prism (GraphPad).

\section{RESULTS}

C1q Binds to Late Apoptotic Cells and Interacts with DNA and Histones-DNA has been previously suggested to act as a $\mathrm{C} 1 \mathrm{q}$ ligand on apoptotic cells (8). To further investigate the relevance of this interaction, surface plasmon resonance was used to analyze the binding affinity between C1q and DNA (Fig. $1, A$ and $B$ ). Biotinylated DNA was immobilized onto a streptavidin chip and C1q was injected at several concentrations. $K_{D}$ derived from the plot of response at equilibrium versus $\mathrm{C} 1 \mathrm{q}$ concentration was estimated to $2.2 \times 10^{-8} \mathrm{M}$ and indicates very strong binding between the two molecules.

To validate the interaction of $\mathrm{C} 1 \mathrm{q}$ and DNA on apoptotic cells, C1q was incubated with apoptotic Jurkat T-cells and the amount of bound $\mathrm{C} 1 \mathrm{q}$ as well as available DNA were assessed using an antibody against dsDNA. C1q did not bind to live Jurkat cells but did bind to apoptotic cells that were induced with $0.75 \mu \mathrm{M}$ staurosporine for at least $6 \mathrm{~h}$ (Fig. 1C). Very weak or no binding occurred to apoptotic cells, which were induced for shorter time, whereas the binding increased with longer induction times (up to $16 \mathrm{~h}$ ). C1q bound to both the A5+/ViaProbe - (early apoptotic) and A5+/Via-Probe+ (late apoptotic/necrotic) populations of cells induced for at least $6 \mathrm{~h}$, whereby it bound stronger to the double positive cells. After 16 h of incubation $\sim 45 \%$ of the cells were A5+/Via-Probeand $45 \%$ were A5+/Via-Probe + . To exclude that serum deprivation alone led to induction of $\mathrm{C} 1 \mathrm{q}$ binding, we tested binding to cells that have been incubated for $16 \mathrm{~h}$ in RPMI without addition of staurosporine. Almost no cells were A5+ or ViaProbe + indicating that $\mathrm{C} 1 \mathrm{q}$ binding is induced by apoptosis (data not shown).

With the apoptosis induction procedure used in this study, an elevated surface level of DNA was detected $4 \mathrm{~h}$ after apoptosis induction and increased strongly with longer induction times (Fig. 1C). This indicates that DNA is present on the surface before C1q starts to bind. Together with the observation that the elevated surface level of DNA rises more strongly than C1q binding, we assumed that DNA cannot be the only C1q ligand on dying cells or that the cell surface must be reorganized before DNA is available for interaction with $\mathrm{C} 1 \mathrm{q}$.

To visualize and confirm the interaction of $\mathrm{C} 1 \mathrm{q}$ and DNA on the surface of apoptotic cells, confocal microscopy was performed (Fig. 1D). Co-localization was calculated for different areas on two microscope slides from separate experiments by using the overlap coefficient $(R)$ according to Manders (30). C1q and DNA displayed a mean coefficient of $0.74 \pm 0.04$, which clearly indicates co-localization. 
DNA can be present as nucleosomes on the surface of apoptotic cells (31) and therefore we tested whether C1q could interact directly with histones. The interaction was evaluated using purified histones from Jurkat T-cells in an ELISA setup. Clear binding of purified $\mathrm{C} 1 \mathrm{q}$ to both $\mathrm{H} 2 \mathrm{~A} / \mathrm{H} 2 \mathrm{~B}+\mathrm{H} 1$ and $\mathrm{H} 3 / \mathrm{H} 4$ histones was observed (Fig. 1E). This interaction was also detected from heat inactivated serum, Hi-NHS (Fig. 1F). To verify whether histones bind to the globular head or to the collagenous tail region of $\mathrm{Clq}$, proteins were immobilized and incubated with radiolabeled histones. Both histone fractions bound mainly to the collagenous tail region of $\mathrm{C} 1 \mathrm{q}$ but binding to the globular head region was also significant (Fig. 1, $G$ and $H$ ). Interaction of histones with $\mathrm{C} 1 \mathrm{q}$ could result in both inhibition and activation of complement depending on the $\mathrm{C} 1 \mathrm{q}$ region involved in the interaction. Therefore immobilized histones were incubated with NHS and deposition of C4b was detected using specific antibodies. Both histone pairs induced strong complement activation (Fig. 1I). To evaluate if C1q was responsible for the observed activation, histones were incubated with C1q-deficient NHS and C1q-deficient NHS reconstituted with $70 \mu \mathrm{g} / \mathrm{ml}$ of purified C1q. Although no deposition was seen in the absence of $\mathrm{C} 1 \mathrm{q}$, surprisingly only histones $\mathrm{H} 3 / \mathrm{H} 4$ were able to induce $\mathrm{C} 4 \mathrm{~b}$ deposition upon reconstitution (Fig. 1). This indicates the presence of other activating factors in NHS that are lacking in the $\mathrm{C} 1 \mathrm{q}$-deficient serum.

Purified Annexins A2 and A5 Bind C1q and Activate the Classical Pathway of Complement-A direct binding assay was used to assess interactions of purified $\mathrm{C} 1 \mathrm{q}$ with annexins $\mathrm{A} 2$ and $\mathrm{A} 5$ immobilized in microtiter plates. C1q bound specifically in a dose-dependent and saturable manner (Fig. $2 A$ ), whereby the binding to annexin A2 was stronger than to annexin A5. Aggregated IgG was used as a positive control and $\alpha_{1}$-antitrypsin as a negative control for $\mathrm{C} 1 \mathrm{q}$ binding. To confirm that $\mathrm{C} 1 \mathrm{q}$ from serum binds to annexin $\mathrm{A} 2$ and $\mathrm{A} 5$, the binding experiment was repeated using NHS as C1q source. Binding to both proteins was confirmed in NHS. The binding of C1q from serum to annexin A5 was comparable with the binding obtained with purified C1q. However, the binding to A2 from serum was much weaker than that of purified C1q (Fig. 2B). This indicates that either the serine proteases $\mathrm{C} 1 \mathrm{r}$ and $\mathrm{C} 1 \mathrm{~s}$, which are present in the $\mathrm{C} 1$ complex or some other serum proteins attenuate the interaction between $\mathrm{C} 1 \mathrm{q}$ and annexin $\mathrm{A} 2$.

To evaluate the nature of the $\mathrm{C} 1 \mathrm{q}$-annexin $\mathrm{A} 2$ and A5 binding, C1q was incubated with immobilized annexins in buffers of varying ionic strength. Both interactions were of ionic nature and the interaction of $\mathrm{C} 1 \mathrm{q}$ to $\mathrm{A} 5$ was more sensitive to the present ionic strength (Fig. 2C). Furthermore, neither the binding of $\mathrm{C} 1 \mathrm{q}$ to annexin $\mathrm{A} 2$ nor to annexin $\mathrm{A} 5$ was dependent on the presence of calcium and magnesium ions (Fig. 2D). Both radiolabeled annexin $\mathrm{A} 2$ and $\mathrm{A} 5$ bound weaker to $\mathrm{C} 1 \mathrm{q}$ heads in comparison to the collagenous tail region (Fig. 2, $E$ and $F$ ). This difference was more pronounced for annexin A2 compared with annexin A5.

We showed recently that annexin A2 is one of the ligands localizing FH to the surface of apoptotic cells (17). Therefore competition experiments were performed whereby annexin A2 was immobilized in microtiter plates and binding of $\mathrm{C} 1 \mathrm{q}$ and $\mathrm{FH}$, respectively, was evaluated in the presence of no, 5-, or
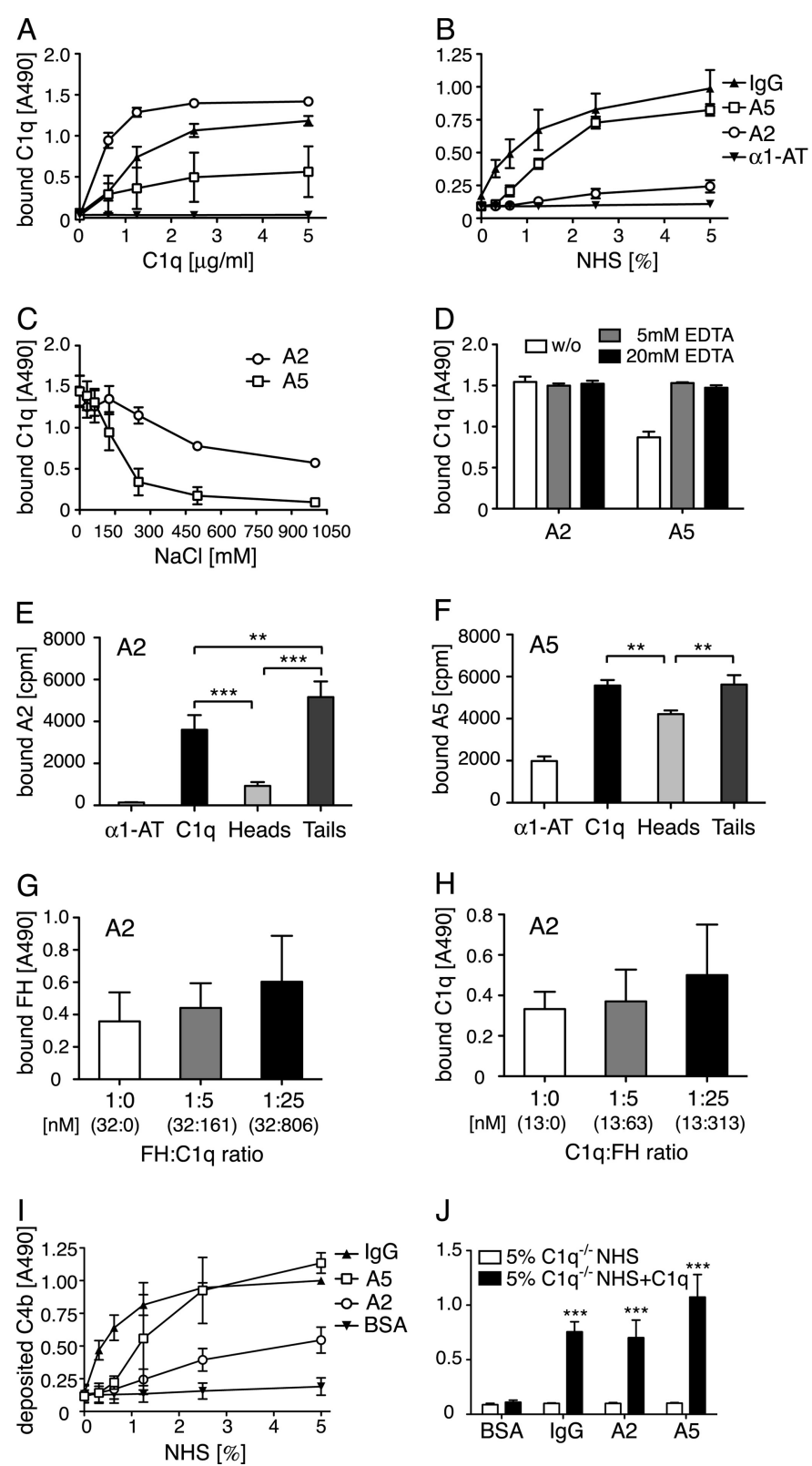

FIGURE 2. Annexin A2 and A5 bind C1 q and activate complement. $A$ and $B$, increasing concentrations of $\mathrm{C} 1 \mathrm{q}$ were incubated with immobilized annexin A2, annexin A5, IgG (positive control), or $\alpha 1$-AT (negative control). Clear binding to both annexins was seen both by purified protein $(A)$ and NHS $(B)$. C and $D, C 1 q(10 \mu \mathrm{g} / \mathrm{ml})$ diluted in buffers with increasing ionic strength or containing 5 or $20 \mathrm{~mm}$ EDTA was added to immobilized annexins. The interaction of $\mathrm{C} 1 \mathrm{q}$ with both annexin $\mathrm{A} 2$ and annexin $\mathrm{A} 5$ decreased with increasing ionic strength $(C)$ but was not dependent on bivalent cations $(D)$. $E$ and $F$, radiolabeled annexin $\mathrm{A} 2$ and $\mathrm{A} 5$ were incubated with immobilized $\mathrm{C} 1 \mathrm{q}, \mathrm{C} 1 \mathrm{q}$ globular heads, C1q collagenous tails, and $\alpha 1$-AT (negative control). After washing, the amount of bound protein was determined in a $\gamma$-counter. The annexins bound well to the collagenous tail region of $\mathrm{C} 1 \mathrm{q}$ and annexin $\mathrm{A} 5$ also bound strongly to the globular head domain of C1q. $G$ and $H$, binding of $\mathrm{C} 1 \mathrm{q}(6.25$ $\mu \mathrm{g} / \mathrm{ml})$ to annexin $\mathrm{A} 2$ was competed with $\mathrm{FH}(G)$ and reverse $(5 \mu \mathrm{g} / \mathrm{ml}$ and $\mathrm{FH}$, $H$ ). The actual concentration of each protein is depicted in nanomolar in parentheses. No competition was observed in either setting. I and J, C4b deposition was measured on annexins or controls from NHS (l), C1q-deficient sera or C1q-deficient sera reconstituted with $70 \mu \mathrm{g} / \mathrm{ml}$ of C1q $(J)$. Clear deposition was seen from NHS, which was completely abolished in C1q-deficient sera and could be restored upon addition of C1q. Values are shown as mean of duplicates, $n=3(E, n=4) \pm$ S.D. $E-H$, significance of differences was calculated using one-way analysis of variance followed by Tukey's multiple comparisons post-test and is displayed as: ${ }^{*}, p<0.05 ;{ }^{*}, p<0.01 ; * * *, p<0.001$. For $J$, the significance of differences was calculated using two-way analysis of variance with a Bonferroni post-test and is displayed as: ${ }^{* *}, p<0.001$. 

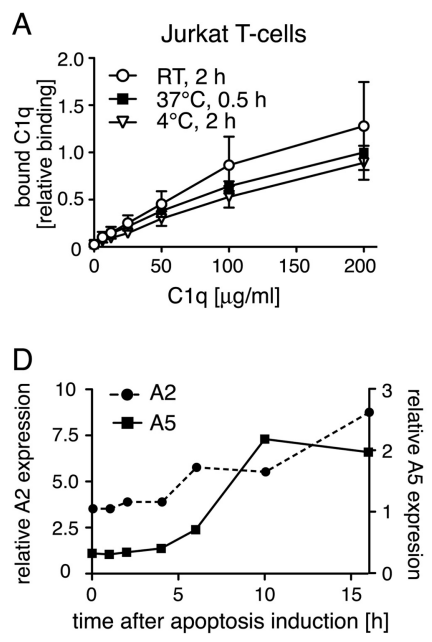
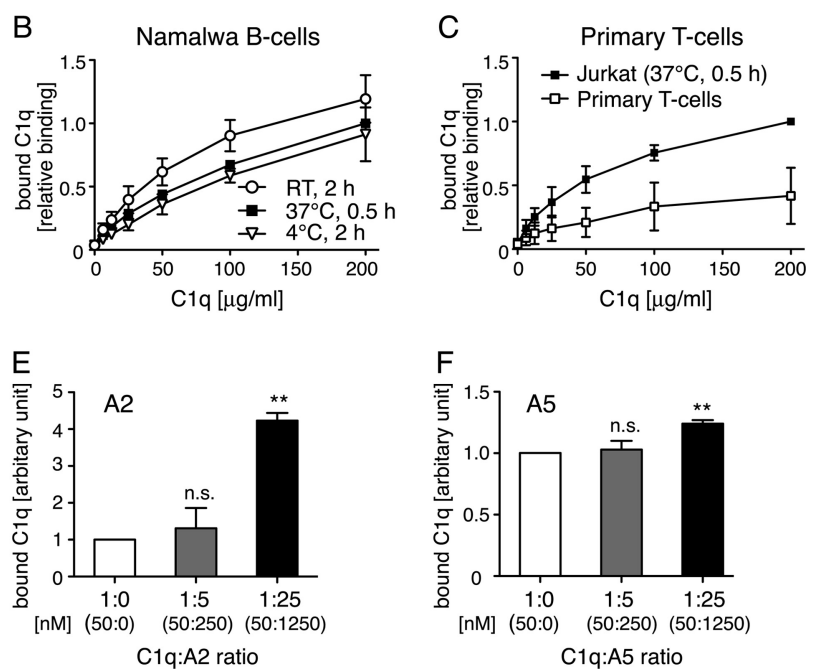

FIGURE 3. C1q binds to apoptotic T- and B-cells and interacts with annexin $\mathbf{A} 2$ and $\mathbf{A} 5$ exposed on the cell surface. $A$ and $B$, binding curves of $C 1 q$ to apoptotic Jurkat T-cells and apoptotic Namalwa B-cells were obtained at different temperatures. C1q bound dose-dependently to both cell lines. C, binding of C1q to apoptotic Jurkat T-cells and apoptotic primary T-lymphocytes. C1q bound dose-dependently, but reached lower levels for primary T-lymphocytes compared with Jurkat T-cells. $D$, change in annexin A5 and A2 expression on the surface of apoptotic Jurkat T-cells expressed relative to antibody controls. Both annexin A2 and A5 expressions increased during the course of apoptosis induction. $E$ and $F$, preincubation of annexin A2 $(E)$ and annexin $A 5(F)$ increased binding of $\mathrm{C} 1 \mathrm{q}(25 \mu \mathrm{g} / \mathrm{ml})$ to apoptotic Jurkat T-cells. The $\Delta$ GeoMean for the binding of $\mathrm{C} 1 \mathrm{q}$ in the absence of competitor was defined as 1 and the binding in the presence of competitor has been calculated in relationship. The actual concentration of each protein is depicted in nanomolar in parentheses. $A-C$, values are shown as mean of three independent experiments, $n=3 \pm$ S.D. Values were normalized to binding for $200 \mu \mathrm{g} / \mathrm{ml}$ of $\mathrm{C} 1 \mathrm{q}$ at $37^{\circ} \mathrm{C}$ for $30 \mathrm{~min}$. $D$, representative values from two independent experiments are shown. For $E$ and $F$, values are shown as mean of three independent experiments, $n=3 \pm$ S.D. Significance of differences was calculated using one-way analysis of variance followed by Dunnett's multiple comparison post-test and is displayed as: $n$.s., not significant; **, $p<0.01$.

25 -fold $\mathrm{M}$ excess of the other protein. Protein and competitor were preincubated at room temperature. Neither FH (Fig. 2G) nor $\mathrm{C} 1 \mathrm{q}$ (Fig. $2 H$ ) competed with the other protein for the binding to immobilized annexin A2.

To assay the complement activating potential of the annexins, immobilized annexin A2 and A5 were incubated with NHS as a source of complement and deposition of $\mathrm{C} 4 \mathrm{~b}$ was detected using specific antibodies. Both annexin A2 and A5 induced complement activation, where activation by annexin A5 was comparable with the strongly activating aggregated IgG (Fig. 2I). The requirement of $\mathrm{C} 1 \mathrm{q}$ for complement activation to occur was confirmed using C1q-deficient NHS as well as reconstituted C1q-deficient NHS. No deposition of C4b was observed for IgG or the two annexins from C1q-deficient NHS, but could be fully restored upon addition of C1q (Fig. 2J).

C1q Binds to Apoptotic T- and B-cells and Interacts with Annexin A2 and A5 Exposed on the Cell Surface-C1q bound dose-dependently to apoptotic Jurkat T-cells and Namalwa B-cells (Fig. 3, $A$ and $B$ ). No significant differences were found when binding of $\mathrm{C} 1 \mathrm{q}$ to apoptotic cells was evaluated at room temperature for $2 \mathrm{~h}$ compared with incubations at $4{ }^{\circ} \mathrm{C}$ for $2 \mathrm{~h}$ or at $37^{\circ} \mathrm{C}$ for $30 \mathrm{~min}$. The incubation at $37^{\circ} \mathrm{C}$ for $30 \mathrm{~min}$ was chosen for all following experiments. Using this setup, C1q bound dose-dependently to apoptotic primary T-lymphocytes, although the binding reached lower levels compared with Jurkat T-cells (Fig. 3C). Both annexin A2 and A5 were only present in a negligible amount on the cell surface of live Jurkat T-cells but both proteins became exposed during the course of apoptosis induction (Fig. 3D). The same course of expression was detected on Namalwa B-cells (data not shown). C1q bound to both annexins when purified proteins were used (Fig. $2 A$ ) and thus we investigated whether externally added annexin A2 or
A 5 could affect the binding of $\mathrm{C} 1 \mathrm{q}$ to apoptotic cells. Both proteins were able to increase the binding of $\mathrm{C} 1 \mathrm{q}$ to the cell surface, confirming interaction in a setting of the whole cell membrane (Fig. 3, $E$ and $F$ ). Due to the fact that both annexins bind to negatively charged phospholipids, which become exposed on the cell surface during apoptosis, it was expected that these proteins, when preincubated with $\mathrm{C} 1 \mathrm{q}$, localize even more $\mathrm{C} 1 \mathrm{q}$ to the cell membrane.

C1q, C4BP, and FH Do Not Compete for One Another's Binding to Apoptotic Cells-C1q, C4BP, and FH have all been proven to bind to apoptotic cells $(3,14,15)$. To clarify whether they influence one another's binding, competition assays were performed. Jurkat T-cells were rendered apoptotic and incubated for $30 \mathrm{~min}$ with $25 \mu \mathrm{g} / \mathrm{ml}$ of C1q, $15 \mu \mathrm{g} / \mathrm{ml}$ of C4BP-Alexa Fluor 488 , or $5 \mu \mathrm{g} / \mathrm{ml}$ of FH-Alexa Fluor 488 either alone or in the presence of 5- or 25-fold $\mathrm{M}$ excess of each of the other proteins separately. The protein and potential competitor were preincubated for $30 \mathrm{~min}$ at room temperature before the addition to the cells. Neither C4BP (Fig. 4B) nor FH (Fig. 4C) competed with C1q binding and neither did C1q compete with C4BP (Fig. 4D) or $\mathrm{FH}$ binding (Fig. $4 E$ ). To verify that the experimental settings were correct, C4BP $(25 \mu \mathrm{g} / \mathrm{ml})$ was also incubated with 5 - and 25-fold $\mathrm{M}$ excess of annexin A5. Both C4BP and annexin A5 bind strongly to negatively charged phospholipids, and annexin A5 was indeed able to compete with C4BP in a statistically significant manner for the binding of apoptotic Jurkat cells at a 5-fold molar excess (Fig. 4A).

C1q Does Not Interact with Phospholipids-To clarify whether $\mathrm{C} 1 \mathrm{q}$ interacts with phospholipids that might be present on the surface of apoptotic cells, surface plasmon resonance was performed using different compositions of extruded liposomes immobilized on an L1 chip. C1q or C4BP, used as a 

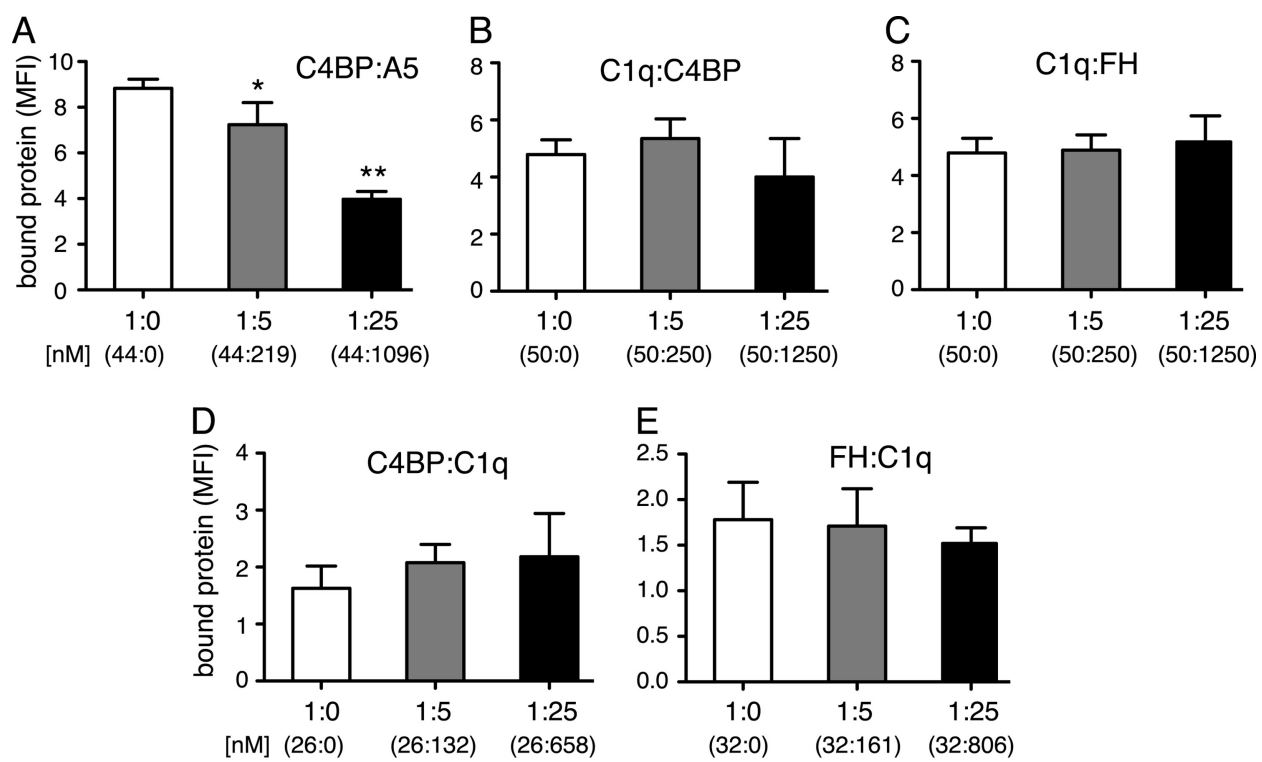

\section{protein:competitor ratio}

FIGURE 4. C1q, C4BP, and FH do not bind the same surface ligand on apoptotic cells. $A-E, C 4 B P, C 1 q$, and FH were allowed to compete with one another for binding to apoptotic cells in 0,5 , and $25 \mathrm{M}$ ratios, whereby the protein and potential competitor had been preincubated for 30 min at room temperature before the addition to the cells. Binding of C4BP $(25 \mu \mathrm{g} / \mathrm{ml})$ was competed out by annexin A5 $(A)$, whereas no competition was seen for any of the other proteins: C1q binding $(25 \mu \mathrm{g} / \mathrm{ml})$ by C4BP $(B), C 1 q$ binding $(25 \mu \mathrm{g} / \mathrm{ml})$ by FH $(C)$, C4BP binding $(15 \mu \mathrm{g} / \mathrm{ml})$ by C1q $(D)$, or FH (5 $\mu \mathrm{g} / \mathrm{ml})$ binding by C1q (E). Data are presented as mean of three independent experiments, $n=3 \pm$ S.D. Significance of differences was calculated using one-way analysis of variance followed by Dunnett's multiple comparison post-test and is displayed as: ${ }^{*}, p<0.05 ;{ }^{* *}, p<0.01$.

positive control, were injected at different concentrations. During the course of apoptosis, endogenous phospholipases are activated that generate lysophospholipids on the apoptotic cell surface (32). Lipid oxidation also occurs during the onset of programmed cell death (33). Therefore $\mathrm{C} 1 \mathrm{q}$ binding to different compositions of lysophospholipids and oxidized phospholipids was also investigated. All tested liposome compositions are listed in Table 1. We found that purified $\mathrm{C} 1 \mathrm{q}$ bound to none of the tested liposomes (data not shown). C4BP on the other hand, as expected, bound strongly to liposomes containing 10\% PS, whereby it bound slightly better to natural PS (Fig. $5 A$ ) than to synthetic PS (Fig. $5 B$ ). The binding constants were determined as $1.09 \times 10^{-7}$ and $1.93 \times 10^{-7} \mathrm{M}$ to natural and synthetic PS containing liposomes, respectively. It bound equally strongly to oxidized and nonoxidized synthetic PS (Fig. 5C). Phosphatidylcholine (PC) alone (100\%) was used as a negative control. C4BP did not interact with lyso-PS, which has not been previously reported.

To confirm the results with a different method, liposomecoated Dynabeads were used for flow cytometry analysis. Binding of C1q-Alexa Fluor $488(150 \mu \mathrm{g} / \mathrm{ml})$ and C4BP-Alexa Fluor $488(50 \mu \mathrm{g} / \mathrm{ml})$ to PE/PC (20/80 $\mathrm{mol} \%)$ and PS/PE/PC (10/ 20/70 mol \%) liposome-coated Dynabeads was determined. As expected, C4BP bound strongly to the PS-containing liposomes, whereas $\mathrm{C} 1 \mathrm{q}$, even when applied in a three times higher concentration, did not bind to these liposomes (Fig. 5D). The signal obtained from the PE/PC liposomes was defined as background binding and set to 1 .

Confocal microscopy was performed to visualize C1q and PS on the surface of apoptotic cells, whereby Alexa Fluor 647-labeled A5 was used to stain PS, and propidium iodide to counterstain nucleic DNA (Fig. 5E). Potential co-localization was calculated for different areas on two microscope slides from separate experiments and the mean overlap coefficient was determined to $0.51 \pm 0.06$, indicating no significant co-localization for C1q and PS. A time course experiment, using the same time points as displayed in Fig. 1, was performed to determine the overlap coefficient for the whole course of apoptosis induction. The overlap coefficient for live cells was $0.14 \pm 0.04$ and increased with time up to $0.51 \pm 0.06$ for the 16 -h induced cells, indicating perhaps that $\mathrm{C} 1 \mathrm{q}$ localized close to PS with the increasing apoptosis but that the two ligands never co-localized strongly.

Comparison of Different Apoptosis Inducers and Their Impact on C4BP, FH, and C1q Binding-To see whether the mode of apoptosis induction influences the binding of C4BP, $\mathrm{FH}$, and $\mathrm{C} 1 \mathrm{q}$ to apoptotic cells, Jurkat T-cells were stimulated with commonly used concentrations of different inducers of the intrinsic (staurosporine, etoposide and camptothecin) or the extrinsic (anti-fas Ab, cycloheximide, and actinomycin D) apoptosis induction pathway. The histograms in Fig. 6 display the binding of $\mathrm{C} 4 \mathrm{BP}(A), \mathrm{C} 1 \mathrm{q}(B)$, and $\mathrm{FH}(C)$ to the whole populations of cells induced to become apoptotic with various agents. The numbers next to the histograms indicate the percentage of early apoptotic cells in the whole cell population. C4BP bound well to all apoptotic cells irrespectively of inducing agent. However, the binding to $\alpha$-fas Ab, cycloheximide, actinomycin D, and etoposide-induced cells was weaker than to camptothecin and staurosporine-induced cells. Apart from the staurosporine-treated cells, for which two peaks appeared in the histogram, only one peak corresponding to bound C4BP was observed for all other inducers (Fig. 6A). C1q bound generally weaker than $\mathrm{C} 4 \mathrm{BP}$ and almost no binding could be detected to the anti-fas $\mathrm{Ab}$ and very little binding to the actino- 


\section{Annexins Bind C1q}

TABLE 1

Phospholipids used for surface plasmon resonance and flow cytometric analyses

C1q did not interact with any of the tested phospholipids.

\begin{tabular}{|c|c|c|c|c|}
\hline Lipid abbreviation & Lipid (underlined) & Lipid source & Mol \% & Treatments \\
\hline$\underline{\mathrm{PC}}$ & 1-Palmitoyl-2-oleoyl-sn-glycero-3-phosphocholine & Synthetic & 100 & \\
\hline$\overline{\mathrm{PS}} / \mathrm{PC}$ & 1-Palmitoyl-2-oleoyl-sn-glycero-3-phospho-L-serine & Synthetic & $10 / 90$ & \\
\hline $\mathrm{PE} / \mathrm{PC}$ & 1-Palmitoyl-2-oleoyl-sn-glycero-3-phosphoethanolamine & Synthetic & $10 / 90$ & \\
\hline LysoPC/PC & 1-Oleoyl-2-hydroxy-sn-glycero-3-phosphocholine & Synthetic & $3 / 97$ & \\
\hline LysoPC/PC & & & $10 / 90$ & \\
\hline LysoPC/PC & & & $60 / 40$ & \\
\hline LysoPS/PC & 1-Oleoyl-2-hydroxy-sn-glycero-3-phospho-L-serine & Synthetic & $60 / 40$ & \\
\hline LysoPE/PC & 1-Oleoyl-2-hydroxy-sn-glycero-3-phosphoethanolamine & Synthetic & $60 / 40$ & \\
\hline LysoPS/PC & & & $10 / 90$ & \\
\hline $\mathrm{PC}$ & & & 100 & Oxidized \\
\hline LysoPC/PC & & & $40 / 60$ & Oxidized \\
\hline LysoPC/PC & & & $40 / 60$ & \\
\hline $\mathrm{PS} / \mathrm{PC}$ & & & $10 / 90$ & Oxidized \\
\hline LysoPS/PC & & & $10 / 90$ & Oxidized \\
\hline Natural PC & L- $\alpha$-Phosphatidylcholine & Egg, chicken & 100 & \\
\hline Natural PS/natural PC & L- $\alpha$-Phosphatidylserine & Brain, porcine & $10 / 90$ & \\
\hline Natural LysoPC/natural PC & L- $\alpha$-Lysophosphatidylcholine & Egg, chicken & $20 / 80$ & \\
\hline
\end{tabular}
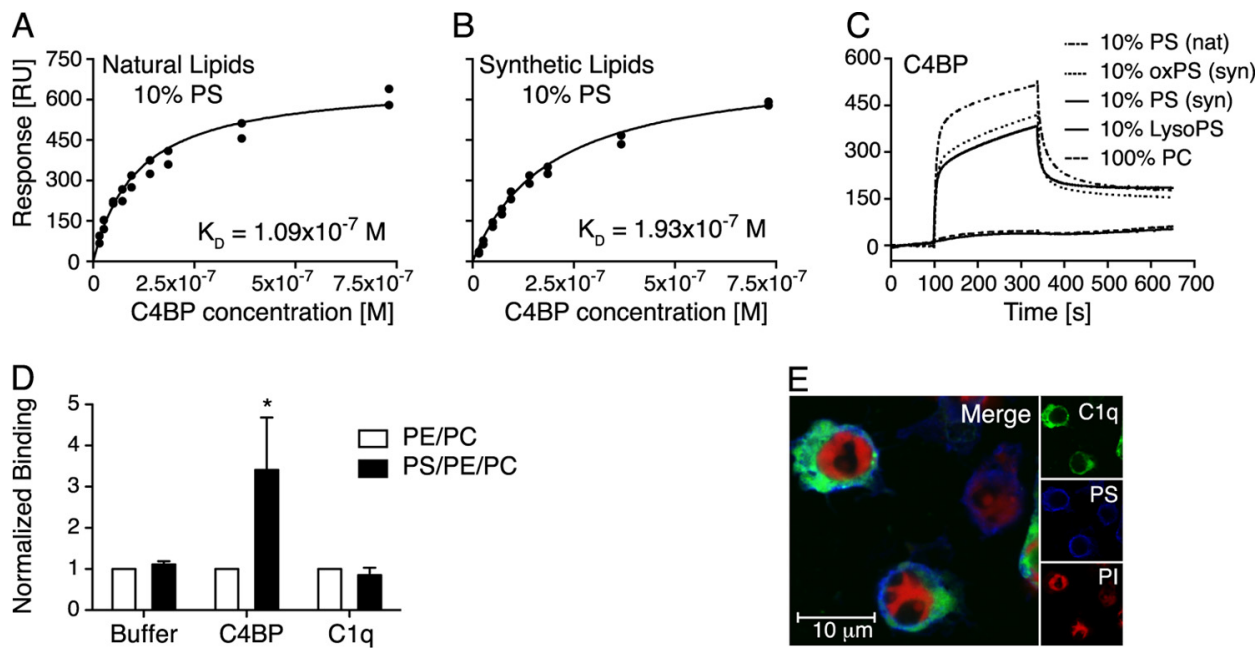

FIGURE 5. C4BP binds both synthetic and natural PS incorporated in liposomes and on apoptotic cells. $A$ and $B$, binding of C4BP to extruded PS-PC liposomes generated with natural $(A)$ and synthetic $(B)$ lipids was assayed using surface plasmon resonance. The response obtained at equilibrium was plotted against $C 4 \mathrm{BP}$ concentrations and $K_{D}$ value of the interaction was determined to $1.09 \times 10^{-7} \mathrm{M}$ for natural lipids and $1.93 \times 10^{-7} \mathrm{M} \mathrm{for} \mathrm{synthetic} \mathrm{lipids.} C$, binding of C4BP to PC liposomes containing PS, oxidized PS as well as lyso-PS was assayed (nat, natural; syn, synthetic). D, binding of Alexa Fluor 488-labeled C4BP (50 $\mu \mathrm{g} / \mathrm{ml})$ and Alexa Fluor 488-labeled C1q $(150 \mu \mathrm{g} / \mathrm{ml})$ to sonicated liposomes containing PC and PE with or without PS was assayed using flow cytometry. E, localizations of Alexa Fluor 488-labeled C1q (green), PS (blue, detected with Alexa Fluor 647-labeled annexin A5), and propidium iodide (PI) (red) on apoptotic cells were studied using confocal microscopy and co-localization was calculated according to Manders et al. (30). $D$, values are shown as mean of three independent experiments, $n=3 \pm$ S.D. Significance of differences was calculated using Welch's $t$ test assuming equal S.D. and is displayed as: ${ }^{*}, p<0.05$. E, one representative image of two independent experiments is shown. $R U$, response units.

mycin D and etoposide-induced cells (Fig. 6B). Only one peak appeared in the histogram for those cells, whereas two peaks were present for the camptothecin and cycloheximide-induced cells and even three peaks for the staurosporine-induced cells. These may be corresponding to two or three distinct cell populations that vary in their ability to bind C1q. FH bound well to all apoptotic cells irrespectively of the induction method (Fig. $6 C)$, whereby the anti-fas Ab-induced cells appeared as one homogenous population (one peak in the histogram). The camptothecin-, cycloheximide-, and etoposide-induced cells were divided into two distinct populations (two peaks) and the staurosporine-induced cells into three distinct populations (three peaks). In general all three proteins bound strongest to staurosporine-induced cells and weakest to anti-fas Ab-induced cells. However, no specific difference in binding strength could be observed between extrinsic or intrinsic apoptosis inducers. None of the three studied proteins bound to live Jurkat cells (data not shown). To verify whether observed different peaks correspond to different stages of apoptosis, the peaks were classified as low, middle, or high intensity binding. Staining with annexin A5 and Via-Probe allowed the differentiation into live (A5-/Via-Probe-), early apoptotic (A5+/Via-Probe-), and late apoptotic (A5+/Via-Probe + ) populations, which are depicted in the dot plots (only for the staurosporine-induced cells). The cells that bound with high intensity (red) to C4BP, $\mathrm{Clq}$ and $\mathrm{FH}$ were, as expected, mainly the late apoptotic population. The cells that bound with middle intensity (yellow) to $\mathrm{C} 1 \mathrm{q}$ and $\mathrm{FH}$ were mainly the early apoptotic population and the cells that bound with low intensity (green) were heterogeneously averaged through all three populations. The percentage of live, early, and late apoptotic cells for all inducers are indicated in Fig. 6D. After a 4-h stimulation with the different inducers, between 30 and $60 \%$ early apoptotic and around 10\% late apoptotic cells were detected. Staurosporine was the only exception here yielding $\sim 35 \%$ late apoptotic cells and thus less than $10 \%$ live cells. 

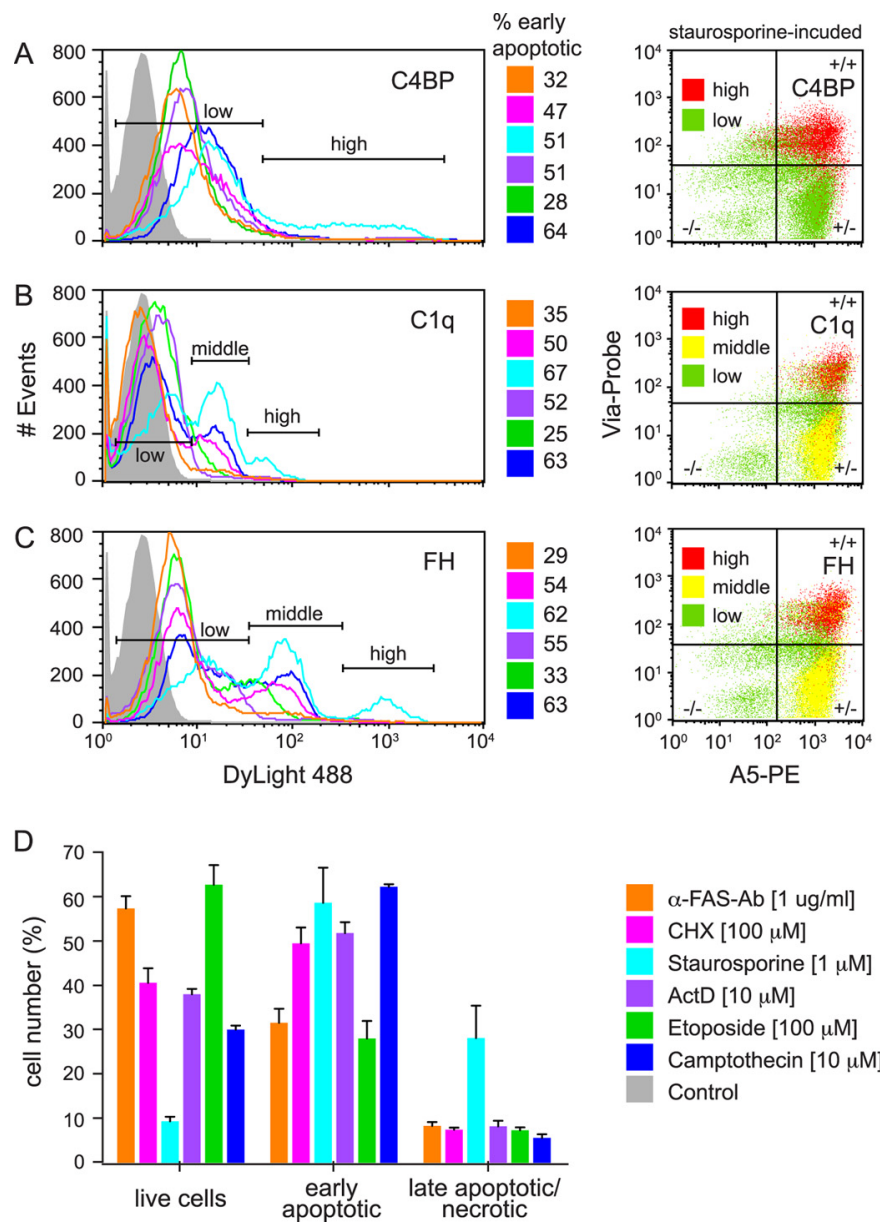

FIGURE 6. C4BP, C1q, and FH bind to apoptotic cells generated by different apoptosis inducers. $A-C$, Jurkat T-cells were rendered apoptotic with different extrinsic and intrinsic apoptosis inducers and the binding of 50 $\mu \mathrm{g} / \mathrm{ml}$ of DyLight 488-labeled C4BP $(A), C 1 \mathrm{q}(B)$, and FH $(C)$ was investigated. All proteins bound to the cells were induced to become apoptotic with various agents, although the binding intensity differed for the individual inducers. Generally, all three proteins bound strongest to the staurosporine-induced cells. The percentage of early apoptotic cells generated in the experiments is indicated beside the flow cytometric histograms. The dot plots display the live (A5-/Via-Probe-), early (A5+/Via-Probe-), and late apoptotic $(\mathrm{A} 5+/ \mathrm{Nia}-\mathrm{Probe}+)$ population of the cells that bound with high (red), middle (yellow), or low (green) intensity to the staurosporine-induced cells. D, percentage of live, early, and late apoptotic cells for all different apoptosis inducers. All inducers, except for staurosporine, generated populations that contained $30-60 \%$ live cells and $10 \%$ late apoptotic cells. Staurosporine-generated apoptotic population contained only $10 \%$ live but $40 \%$ late apoptotic cells. All inducers generated $30-60 \%$ early apoptotic cells. $A-C$, representative histograms and dot plots of two independent experiments performed in duplicates in which the binding was once detected with labeled proteins (shown data) and once with FITC-labeled antibodies (data not shown) are presented. $D$, the mean \pm S.D. for the cells treated with DyLight 488-labeled $\mathrm{C} 4 \mathrm{BP}, \mathrm{C} 1 \mathrm{q}$, and $\mathrm{FH}$ are shown.

\section{DISCUSSION}

Proper clearance of apoptotic cells is crucial to secure homeostasis. For this purpose, a complex and multifaceted system has evolved containing a vast range of recognition mechanisms of the apoptotic cells from down-regulation of "do not eat me" signals to up-regulation of "find me" as well as "eat me" signals. Deficiencies of key components of this complex network such as $\mathrm{C1q}$ as well as phagocytic receptors decrease the efficiency of clearance, causing apoptotic cells to lose their integrity before being properly cleared. This in turn leads to a more inflamma- tory environment, which could induce the formation of autoantibodies paving the path for development of autoimmunity.

C1q has been shown to interact with apoptotic cells both directly (7), which is the subject of this study, and indirectly via C-reactive protein (34), serum amyloid P, pentraxin 3 (35), and natural IgM (36). DNA has long been known as a ligand for C1q and here we further characterized the interaction by determining the $K_{D}$ value using surface plasmon resonance, confirming a very strong interaction. However, due to the fact that $\mathrm{C} 1 \mathrm{q}$ binds at a later stage to apoptotic cells than DNA becomes present on their surface and with different kinetics over induction time, we hypothesized that there must be other ligands. Histones are present on apoptotic cells in the form of nucleosomes. The pentraxins C-reactive protein and serum amyloid $\mathrm{P}$ have been shown to bind to histones and activate the classical complement pathway (37). Here we showed that $\mathrm{C} 1 \mathrm{q}$ also binds directly to histones, which leads to complement activation. C4b deposition on all histone complexes was abolished in C1q-deficient sera but surprisingly it could not be restored upon addition of $\mathrm{C} 1 \mathrm{q}$ for the histone complex $\mathrm{H} 2 \mathrm{~A} / \mathrm{H} 2 \mathrm{~B}+\mathrm{H} 1$, even though deposition was restored for both IgG and $\mathrm{H} 3 / \mathrm{H} 4$. This indicates that there is a factor additional to $\mathrm{Clq}$ lacking in the C1q-deficient sera, which is required for complement activation by $\mathrm{C} 1 \mathrm{q}$ on the $\mathrm{H} 2 \mathrm{~A} / \mathrm{H} 2 \mathrm{~B}+\mathrm{H} 1$ complex, which is not needed for complement activation on $\mathrm{H} 3 / \mathrm{H} 4$. We further assayed MBL, factor D, and COLEC11 as well as ficolin-L and ficolin- $\mathrm{H}$ activity in the different sera, but all tested proteins were functional in both C1q-deficient sera and in the control sera (not shown). The importance of the interaction between C1q and nucleosomes (DNA and histones) on apoptotic cells is underscored by the observation that patients with low serum levels of immune complex-containing DNA at the onset of a flare developed a more severe flare compared with patients for whom the level remained stable. This coincided with low C1q serum levels and high disease activity and was not seen among patients with normal levels of C1q at flare (38).

C1q bound dose-dependently to Jurkat T- and Namalwa B-cells with the binding not becoming completely saturated at the concentrations used. We revealed that there are at least four different and abundant ligands for $\mathrm{C} 1 \mathrm{q}$ on the surface of apoptotic cells. The surface expression of annexins A2 and A5, DNA, and histones increases during the course of apoptosis induction. Hence the overall concentration of possible ligands for C1q is very high on the 16-h induced cells and it is likely that the binding cannot be fully saturated unless very high concentrations are used. The binding of C1q to primary T-lymphocytes was also dose-dependent, almost saturated, and reaching lower levels than for Jurkat T-cells. Primary T-lymphocytes are much smaller than Jurkat $\mathrm{T}$-cells and thus exhibit a lesser total amount of ligands for $\mathrm{C} 1 \mathrm{q}$. As a consequence, the molar ratio of $\mathrm{C} 1 \mathrm{q}$ to $\mathrm{C} 1 \mathrm{q}$ ligands is larger and the binding saturates at lower concentrations.

Annexin A2 and A5 are both present in serum $(39,40)$ and can bind negatively charged phospholipids. Additionally, their surface expression on lymphocytes increases during apoptosis. $\mathrm{C} 1 \mathrm{q}$ preincubated with annexins therefore bound stronger to the apoptotic cell surface and this might be relevant also in an in vivo situation. Depending on the apoptosis stage, annexins A2 


\section{Annexins Bind C1q}

and A5 co-localized with C1q on some cells, most likely the later apoptotic ones. No co-localization was found on another population of cells, which comprises most likely the early apoptotic ones (data not shown).

PS has been reported to function as a C1q ligand (13), but we could not find experimental evidence for this hypothesis in our assays. Using annexin A5, we found PS already exposed on the cell surface at an early time point $(\sim 1 \mathrm{~h})$ after apoptosis induction and detected a further increase with induction time up to $4 \mathrm{~h}$. After this time point, almost no further elevation was detected (data not shown). C1q binding occurred significantly later and increased further over the whole induction time. Additionally, we did not detect any interaction of C1q with PS included in liposomes that were immobilized either on L1 chips in Biacore or on beads and analyzed by flow cytometry. The positive control, C4BP-protein $\mathrm{S}$ complex bound as expected to PS. Finally, we did not detect significant co-localization of C1q and PS on apoptotic cells at various time points of apoptotic cell induction from early to late apoptotic cells. If C1q bound PS on apoptotic cells we would expect that $\mathrm{C} 1 \mathrm{q}$ could compete with $\mathrm{C} 4 \mathrm{BP}$ (or the reverse) for binding to apoptotic cells, as A5 does. However, no such competition could be observed. In the same set up, we did not see any competition for $\mathrm{C} 1 \mathrm{q}$ with $\mathrm{FH}$, which is in concordance with a recent report (41). The discrepancies with the study by Paidassi et al. (13) might arise from technical differences because that study employed HeLa cells, an epithelial carcinoma cell line, induced to become apoptotic using UV irradiation. HeLa cells were trypsinized for the experiments and it must be kept in mind that trypsinzation might have removed protein ligands for $\mathrm{C} 1 \mathrm{q}$ on the surface. In addition, liposomes containing $100 \%$ PS, PE, or PC were used to study binding of $\mathrm{C} 1 \mathrm{q}$ by surface plasmon resonance. This approach is less accurate than our employed mixtures of PC with PS and PE, because even though PS appears in patches on the surface of apoptotic cells, there are always other lipids present. In addition, whereas the confocal pictures presenting co-localization between $\mathrm{C} 1 \mathrm{q}$ and PS looked very convincing, no appropriate software was used to objectively quantify the degree of co-localization. Our software analysis of images found no significant co-localization. An inhibitory effect of annexin A5 on the binding of C1q was also determined, after cells were preincubated with annexin A5 and then C1q was applied. We on the other hand preincubated the two proteins together and then added the mixture to the cells and thus detected increased C1q binding, possibly due to a bridging function of annexin $\mathrm{A} 5$ in guiding bound $\mathrm{C} 1 \mathrm{q}$ to negatively charged phospholipids.

Furthermore, we found no interaction of C1q with oxidized liposomes, which are normally found on apoptotic cells (33) or myeloperoxidase-treated apoptotic cells. Inclusion of lyso-PS in liposomes did not generate $\mathrm{C} 1 \mathrm{q}$ binding but abolished binding of the C4BP-protein S, which binds with high affinity to PS. Interestingly, the interaction of C4BP-protein $\mathrm{S}$ to PS was not affected by oxidation of the lipids, which is in contrast to what has been observed for free, recombinant protein S (42).

Association of inherited C1q deficiency and SLE is very strong, but it is also very rare and thus not responsible for the majority of SLE cases. It is therefore possible that there are other factors preventing interaction of $\mathrm{C} 1 \mathrm{q}$ with apoptotic cells in SLE patients, such as autoantibodies to C1q ligands. Interestingly, autoantibodies to both annexin A2 and annexin A5 $(21,22)$, as well as to other C1q ligands and C1q itself $(43,44)$, have been found in patients suffering from autoimmune diseases such as SLE. These antibodies could either decrease direct binding of C1q to apoptotic cells or recruit additional C1q. Both scenarios could lead to an imbalance in complement activation, which could result in either insufficient removal of the cells or excessive complement activation resulting in a proinflammatory environment. Both are commonly seen in SLE.

The fact that $\mathrm{C} 1 \mathrm{q}$ deficiency is a much stronger genetic risk factor for development of SLE than deficiency of C4 or C2 (45) suggests that $\mathrm{C} 1 \mathrm{q}$ has a unique function in addition to initiation of complement leading to the opsonization with C3b. To support this, evidence has been presented supporting the role of C1q in development of tolerance (46), clearance of immune complexes (47), and cytokine regulation (48). It differentially modulates the phagocytosis and cytokine responses during ingestion of apoptotic cells by human monocytes, macrophages, and dendritic cells as well as of apoptotic neurons by microglia $(49,50)$. Clearly, C1q has many functions crucial for homeostasis and prevention of SLE. Accordingly, low serum levels of C1q correlates with severe active SLE (51).

Apoptosis can be induced by two distinct pathways, the intrinsic and the extrinsic. It has been shown that the percentage of generated early and late apoptotic cells depends on the inducing agent. This on the other hand influences among others the amount of released DNA by Jurkat T-cells and monocytic U937 cells (52). Lesional late-stage scleroderma fibroblasts have been shown to be relatively resistant to Fas-induced apoptosis, but sensitive to intrinsic induction (53). In the current study we found that the method of inducing apoptosis did influence the binding of $\mathrm{C} 1 \mathrm{q}$ and the complement inhibitors, $\mathrm{C} 4 \mathrm{BP}$ and $\mathrm{FH}$, to apoptotic Jurkat T-cells. All three proteins bound to the majority of apoptotic cells independently of the route of apoptosis induction although the intensity of binding differed strongly. Furthermore, no general difference was observed between intrinsic or extrinsic inducers and the order of binding strength with which all three proteins bound to the differently induced cells was the same, even though all three proteins bind at least partially to different ligands and did not compete for one another's binding. Jurkat T-cells are transformed cells and the results obtained might be different for primary cells. Some apoptosis inducers generated cells that bound $\mathrm{C} 1 \mathrm{q}$ with high, middle, and/or low intensity. As expected, the late apoptotic cells mainly bound C1q with high intensity and a quite homogenous population of early apoptotic cells bound with middle intensity. Interestingly, the low intensity binding cells were averaged heterogeneously through the live, early, and late apoptotic populations. This indicates that it is not sufficient for a cell to become apoptotic (as determined by annexin $\mathrm{A} 5$ and Via-Probe staining) to bind $\mathrm{C} 1 \mathrm{q}$ and that, other surface changes also must occur to induce C1q binding. Such changes may involve increased surface expression and spatial organization of endogenous annexin A2, A5, DNA, or histones or of yet unknown additional ligands.

In conclusion, the current study further characterizes the interactions of complement and apoptotic cells and reveals two 
members of the annexin family, annexin A2 and A5, as new ligands for $\mathrm{C} 1 \mathrm{q}$ on dying cells. This phenomenon gives a further explanation for the observations of the presence of pathologic annexin autoantibodies in SLE. This study hence sheds new light on the interactions underlying complement-mediated clearance of apoptotic cells and helps to further the understanding of the pathophysiology of autoimmune diseases such as SLE.

Acknowledgments-We thank Dr. L. A. Trouw for help with the Biacore experiment assessing affinity of C1q-DNA interaction and Dr. Ben King for language revision of the manuscript.

\section{REFERENCES}

1. Ricklin, D., Hajishengallis, G., Yang, K., and Lambris, J. D. (2010) Complement, a key system for immune surveillance and homeostasis. Nat. Immunol. 11, 785-797

2. Wallis, R., Mitchell, D. A., Schmid, R., Schwaeble, W. J., and Keeble, A. H. (2010) Paths reunited. Initiation of the classical and lectin pathways of complement activation. Immunobiology 215, 1-11

3. Korb, L. C., and Ahearn, J. M. (1997) C1q binds directly and specifically to surface blebs of apoptotic human keratinocytes. Complement deficiency and systemic lupus erythematosus revisited. J. Immunol. 158, 4525-4528

4. Ogden, C. A., deCathelineau, A., Hoffmann, P. R., Bratton, D., Ghebrehiwet, B., Fadok, V. A., and Henson, P. M. (2001) C1q and mannose binding lectin engagement of cell surface calreticulin and CD91 initiates macropinocytosis and uptake of apoptotic cells. J. Exp. Med. 194, 781-795

5. Navratil, J. S., Watkins, S. C., Wisnieski, J. J., and Ahearn, J. M. (2001) The globular heads of C1q specifically recognize surface blebs of apoptotic vascular endothelial cells. J. Immunol. 166, 3231-3239

6. Vandivier, R. W., Ogden, C. A., Fadok, V. A., Hoffmann, P. R., Brown, K. K., Botto, M., Walport, M. J., Fisher, J. H., Henson, P. M., and Greene, K. E. (2002) Role of surfactant proteins A, D, and C1q in the clearance of apoptotic cells in vivo and in vitro. Calreticulin and CD91 as a common collectin receptor complex. J. Immunol. 169, 3978-3986

7. Nauta, A. J., Trouw, L. A., Daha, M. R., Tijsma, O., Nieuwland, R., Schwaeble, W. J., Gingras, A. R., Mantovani, A., Hack, E. C., and Roos, A. (2002) Direct binding of C1q to apoptotic cells and cell blebs induces complement activation. Eur. J. Immunol. 32, 1726-1736

8. Elward, K., Griffiths, M., Mizuno, M., Harris, C. L., Neal, J. W., Morgan, B. P., and Gasque, P. (2005) CD46 plays a key role in tailoring innate immune recognition of apoptotic and necrotic cells. J. Biol. Chem. 280, 36342-36354

9. Jiang, H., Cooper, B., Robey, F. A., and Gewurz, H. (1992) DNA binds and activates complement via residues $14-26$ of the human C1q A chain. J. Biol. Chem. 267, 25597-25601

10. Kishore, U., Gupta, S. K., Perdikoulis, M. V., Kojouharova, M. S., Urban, B. C., and Reid, K. B. (2003) Modular organization of the carboxyl-terminal, globular head region of human C1q A, B, and C chains. J. Immunol. $171,812-820$

11. Palaniyar, N., Nadesalingam, J., Clark, H., Shih, M. J., Dodds, A. W., and Reid, K. B. (2004) Nucleic acid is a novel ligand for innate, immune pattern recognition collectins surfactant proteins $A$ and $D$ and mannose-binding lectin. J. Biol. Chem. 279, 32728-32736

12. Tissot, B., Daniel, R., and Place, C. (2003) Interaction of the $\mathrm{C} 1$ complex of complement with sulfated polysaccharide and DNA probed by single molecule fluorescence microscopy. Eur. J. Biochem. 270, 4714-4720

13. Païdassi, H., Tacnet-Delorme, P., Garlatti, V., Darnault, C., Ghebrehiwet, B., Gaboriaud, C., Arlaud, G. J., and Frachet, P. (2008) C1q binds phosphatidylserine and likely acts as a multiligand-bridging molecule in apoptotic cell recognition. J. Immunol. 180, 2329-2338

14. Webb, J. H., Blom, A. M., and Dahlbäck, B. (2002) Vitamin K-dependent protein $\mathrm{S}$ localizing complement regulator $\mathrm{C} 4 \mathrm{~b}$-binding protein to the surface of apoptotic cells. J. Immunol. 169, 2580-2586

15. Trouw, L. A., Bengtsson, A. A., Gelderman, K. A., Dahlbäck, B., Sturfelt,
G., and Blom, A. M. (2007) C4b-binding protein and factor H compensate for the loss of membrane-bound complement inhibitors to protect apoptotic cells against excessive complement attack. J. Biol. Chem. 282, $28540-28548$

16. Trouw, L. A., Nilsson, S. C., Gonçalves, I., Landberg, G., and Blom, A. M. (2005) C4b-binding protein binds to necrotic cells and DNA, limiting DNA release and inhibiting complement activation. J. Exp. Med. 201, 1937-1948

17. Leffler, J., Herbert, A. P., Norström, E., Schmidt, C. Q., Barlow, P. N., Blom, A. M., and Martin, M. (2010) Annexin-II, DNA, and histones serve as factor $\mathrm{H}$ ligands on the surface of apoptotic cells. J. Biol. Chem. 285, $3766-3776$

18. Iaccarino, L., Ghirardello, A., Canova, M., Zen, M., Bettio, S., Nalotto, L., Punzi, L., and Doria, A. (2011) Anti-annexins autoantibodies. Their role as biomarkers of autoimmune diseases. Autoimmun. Rev. 10, 553-558

19. Gerke, V., Creutz, C. E., and Moss, S. E. (2005) Annexins, linking $\mathrm{Ca}^{2+}$ signalling to membrane dynamics. Nat. Rev. Mol. Cell. Biol. 6, 449-461

20. Hayes, M. J., and Moss, S. E. (2004) Annexins and disease. Biochem. Biophys. Res. Commun. 322, 1166-1170

21. Ao, W., Zheng, H., Chen, X. W., Shen, Y., and Yang, C. D. (2011) Antiannexin II antibody is associated with thrombosis and/or pregnancy morbidity in antiphospholipid syndrome and systemic lupus erythematosus with thrombosis. Rheumatol. Int. 31, 865-869

22. Hrycek, A., and Cieślik, P. (2012) Annexin A5 and anti-annexin antibodies in patients with systemic lupus erythematosus. Rheumatol. Int. 32, $1335-1342$

23. Dahlbäck, B. (1983) Purification of human C4b-binding protein and formation of its complex with vitamin K-dependent protein S. Biochem. J. 209, 847-856

24. Blom, A. M., Kask, L., and Dahlbäck, B. (2003) CCP1-4 of the C4b-binding protein $\alpha$-chain are required for factor I mediated cleavage of complement factor C3b. Mol. Immunol. 39, 547-556

25. Tenner, A. J., Lesavre, P. H., and Cooper, N. R. (1981) Purification and radiolabeling of human C1q. J. Immunol. 127, 648-653

26. Kask, L., Trouw, L. A., Dahlbäck, B., and Blom, A. M. (2004) The C4bbinding protein-protein $\mathrm{S}$ complex inhibits the phagocytosis of apoptotic cells. J. Biol. Chem. 279, 23869-23873

27. Laurell, C. B., Dahlqvist, I., and Persson, U. (1983) The use of thiol-disulfide exchange chromatography for the automated isolation of $\alpha_{1}$-antitrypsin and other plasma proteins with reactive thiol groups. J. Chromatogr. 278, 53-61

28. Pâques, E. P., Huber, R., Priess, H., and Wright, J. K. (1979) Isolation of the globular region of the subcomponent q of the $\mathrm{C} 1$ component of complement. Hoppe-Seyler's Z. Physiol. Chem. 360, 177-183

29. Krisinger, M. J., Guo, L. J., Salvagno, G. L., Guidi, G. C., Lippi, G., and Dahlbäck, B. (2009) Mouse recombinant protein C variants with enhanced membrane affinity and hyper-anticoagulant activity in mouse plasma. FEBS J. 276, 6586-6602

30. Manders, E. M., Verbeek, F. J., and Aten, J. A. (1993) Measurement of colocalization of objects in dual-color confocal images. J. Microsc. 169, 375-382

31. Radic, M., Marion, T., and Monestier, M. (2004) Nucleosomes are exposed at the cell surface in apoptosis. J. Immunol. 172, 6692-6700

32. Taketo, M. M., and Sonoshita, M. (2002) Phospholipase $\mathrm{A}_{2}$ and apoptosis. Biochim. Biophys. Acta 1585, 72-76

33. Buttke, T. M., and Sandstrom, P. A. (1994) Oxidative stress as a mediator of apoptosis. Immunol. Today 15, 7-10

34. Mihlan, M., Stippa, S., Józsi, M., and Zipfel, P. F. (2009) Monomeric CRP contributes to complement control in fluid phase and on cellular surfaces and increases phagocytosis by recruiting factor H. Cell Death Differ. 16, $1630-1640$

35. Nauta, A. J., Bottazzi, B., Mantovani, A., Salvatori, G., Kishore, U., Schwaeble, W. J., Gingras, A. R., Tzima, S., Vivanco, F., Egido, J., Tijsma, O., Hack, E. C., Daha, M. R., and Roos, A. (2003) Biochemical and functional characterization of the interaction between pentraxin 3 and $\mathrm{C} 1 \mathrm{q}$. Eur. J. Immunol. 33, 465-473

36. Chen, Y., Park, Y. B., Patel, E., and Silverman, G. J. (2009) IgM antibodies to apoptosis-associated determinants recruit $\mathrm{C} 1 \mathrm{q}$ and enhance dendritic cell 


\section{Annexins Bind C1q}

phagocytosis of apoptotic cells. J. Immunol. 182, 6031-6043

37. Hicks, P. S., Saunero-Nava, L., Du Clos, T. W., and Mold, C. (1992) Serum amyloid $\mathrm{P}$ component binds to histones and activates the classical complement pathway. J. Immunol. 149, 3689-3694.

38. Bengtsson, A., Nezlin, R., Shoenfeld, Y., and Sturfelt, G. (1999) DNA levels in circulating immune complexes decrease at severe SLE flares. Correlation with complement component C1q. J. Autoimmun. 13, 111-119

39. Ji, N. Y., Park, M. Y., Kang, Y. H., Lee, C. I., Kim, D. G., Yeom, Y. I., Jang, Y. J., Myung, P. K., Kim, J. W., Lee, H. G., Lee, K., and Song, E. Y. (2009) Evaluation of annexin II as a potential serum marker for hepatocellular carcinoma using a developed sandwich ELISA method. Int. J. Mol. Med. 24, 765-771

40. Matsuda, R., Kaneko, N., Kikuchi, M., Chiwaki, F., Toda, M., Ieiri, T., Horikawa, Y., Shimizu, M., and Shimamoto, K. (2003) Clinical significance of measurement of plasma annexin $\mathrm{V}$ concentration of patients in the emergency room. Resuscitation 57, 171-177

41. Kang, Y. H., Urban, B. C., Sim, R. B., and Kishore, U. (2012) Human complement factor $\mathrm{H}$ modulates $\mathrm{C} 1 \mathrm{q}$-mediated phagocytosis of apoptotic cells. Immunobiology 217, 455-464

42. Baroni, M., Pavani, G., Marescotti, D., Kaabache, T., Borgel, D., Gandrille, S., Marchetti, G., Legnani, C., D’Angelo, A., Pinotti, M., and Bernardi, F. (2010) Membrane binding and anticoagulant properties of protein S natural variants. Thromb. Res. 125, e33-39

43. Trouw, L. A., and Daha, M. R. (2005) Role of anti-C1q autoantibodies in the pathogenesis of lupus nephritis. Expert Opin. Biol. Ther. 5, 243-251

44. Shoenfeld, Y., Szyper-Kravitz, M., Witte, T., Doria, A., Tsutsumi, A., Tatsuya, A., Dayer, J. M., Roux-Lombard, P., Fontao, L., Kallenberg, C. G., Bijl, M., Matthias, T., Fraser, A., Zandman-Goddard, G., Blank, M., Gilburd, B., and Meroni, P. L. (2007) Autoantibodies against protective molecules, C1q, C-reactive protein, serum amyloid P, mannose-binding lectin, and apolipoprotein A1. Prevalence in systemic lupus erythematosus. Ann. N.Y. Acad. Sci. 1108, 227-239
45. Truedsson, L., Bengtsson, A. A., and Sturfelt, G. (2007) Complement deficiencies and systemic lupus erythematosus. Autoimmunity 40, 560-566

46. Baruah, P., Simpson, E., Dumitriu, I. E., Derbyshire, K., Coe, D., Addey, C., Dyson, J., Chai, J. G., Cook, T., Scott, D., and Botto, M. (2010) Mice lacking $\mathrm{C} 1 \mathrm{q}$ or $\mathrm{C} 3$ show accelerated rejection of minor $\mathrm{H}$ disparate skin grafts and resistance to induction of tolerance. Eur. J. Immunol. 40, 1758-1767

47. Davies, K. A., Hird, V., Stewart, S., Sivolapenko, G. B., Jose, P., Epenetos, A. A., and Walport, M. J. (1990) A study of in vivo immune complex formation and clearance in man. J. Immunol. 144, 4613-4620

48. Lood, C., Gullstrand, B., Truedsson, L., Olin, A. I., Alm, G. V., Rönnblom, L., Sturfelt, G., Eloranta, M. L., and Bengtsson, A. A. (2009) C1q inhibits immune complex-induced interferon- $\alpha$ production in plasmacytoid dendritic cells. A novel link between C1q deficiency and systemic lupus erythematosus pathogenesis. Arthritis Rheum. 60, 3081-3090

49. Fraser, D. A., Laust, A. K., Nelson, E. L., and Tenner, A. J. (2009) C1q differentially modulates phagocytosis and cytokine responses during ingestion of apoptotic cells by human monocytes, macrophages, and dendritic cells. J. Immunol. 183, 6175-6185

50. Fraser, D. A., Pisalyaput, K., and Tenner, A. J. (2010) C1q enhances microglial clearance of apoptotic neurons and neuronal blebs, and modulates subsequent inflammatory cytokine production. J. Neurochem. 112, 733-743

51. Sturfelt, G., Johnson, U., and Sjöholm, A. G. (1985) Sequential studies of complement activation in systemic lupus erythematosus. Scand. J. Rheumatol. 14, 184-196

52. Choi, J. J., Reich, C. F., 3rd, and Pisetsky, D. S. (2004) Release of DNA from dead and dying lymphocyte and monocyte cell lines in vitro. Scand. J. Immunol. 60, 159-166

53. Chabaud, S., Corriveau, M. P., Grodzicky, T., Senécal, J. L., Chartier, S., Raymond, Y., and Moulin, V. J. (2011) Decreased secretion of MMP by nonlesional late-stage scleroderma fibroblasts after selection via activation of the apoptotic Fas-pathway. J. Cell. Physiol. 226, 1907-1914 